\title{
FAKTOR-FAKTOR YANG MEMPENGARUHI PENINGKATAN PENDAPATAN PETANI PADI (Studi Kasus Pada Petani Pemilik Lahan Desa Blang Pha, Kecamatan Seunuddon, Kabupaten Aceh Utara)
}

Afrizal $^{\mathrm{a}^{*}}$, Umaruddin Usman ${ }^{\mathrm{a}^{*}}$

${ }^{a}$ Fakultas Ekonomi dan Bisnis Universitas Malikussaleh

*Corresponding author : afrizalekp@gmail.com

*umaruddinusman@unimal.ac.id

ARTICLE INFORMATION ABSTRACT

\section{Keywords:}

Production Costs, Land Area, Production Results and Farmer Income.
This study aims to determine the factors that influence the income of rice farmers in Blang Pha Village, Seunuddon District, North Aceh Regency. This study uses purposive sampling by distributing questionnares to 70 farmers owning land. The study utilizes multiple linear regression four analiyzing. The results showed that, production costs (XI) and land area (X2) had a positive and significant effect on farmers' income. Furthermore, the number of products did not significantly influence farmers' incomes.

\section{PENDAHULUAN}

Sektor pertanian adalah sektor yang sangat penting bagi perkembangan perekonomian Indonesia baik sebagai sumber bahan makanan dan sumber bahan mentah untuk industri, sebagai lapangan pekerjaan, sumber devisa, serta sebagai pasar barang dan jasa bagi sektor-sektor lain. Sebagian besar penduduk Indonesia berpenghasilan rendah, sehingga usaha untuk peningkatan sektor pertanian adalah sektor yang paling tepat untuk meningkatkan pendapatan ekonomi masyarakat.

Dimasa sekarang ini pertanian adalah sektor yang paling besar peluangnya untuk meningkatkan pendapatan masyarakat, sehingga masyarakat berbondong-bondong untuk melakukan pertanian yang lebih luas dan dapat mencapai produktivitas hasil pertanian semaksimal mungkin sehingga perekonomian petani bisa menuju kearah yang lebih baik.

Produktivitas adalah rasio antara outputdan input dari suatu proses produksi dalam periode tertentu(Mangkuprawira, 2007). Produktivitas pertanian dipengaruhi oleh input dan output dari pertanian. Input dari pertanian meliputi modal, lahan pertanian, tenaga kerja, dan teknologi, sedangkan output dari pertanian meliputi hasil pertanian yang dikelola misalnya padi, selain itu produktivitas di bidang pertanian juga tidak lepas dari faktor-faktor sosial ekonomi yang ada disekitarnya. Faktor ekonomi meliputi pemanfaatan teknologi (Mangkuprawira, 2007). Pemamfaatan teknologi diukur dengan penggunaan bibit, penggunaan pupuk, penggunaan pestisida dan peralatan pertanian. Pemanfaatan teknologi ini harus diseimbangkan dengan sumber daya manusia (SDM) yang tersedia karena SDM merupakan komponen penting dalam peningkatan produksi, karena keberhasilan kinerja individu petani sangat berpengaruh terhadap hasil kerja pertanian (Astuti, 2013).

Provinsi Aceh merupakan daerah yang kaya akan sumber daya alamnya,tanahnya yang subur, luas lahannya, dan penduduknya rata-rat bekerja sebagai petani padi, pendayagunaan sumberdaya pertanian menjadi kunci dalam meningkatkan produktivitas pertanian sehingga sumber daya yang terbatas harus di alokasikan seefisien mungkin. Indonesia merupakan sebuah negara berkembang dengan sektor pertanian 
sebagai mata pecharian dari mayoritas penduduknya pada sektor pertanian dimana penguasaan lahan diwilayah indonesiayang digunakan sebagai lahan pertanian (Husodo, 2004).

Kabupaten Aceh Utara memiliki potensi sektor pertanian yang cukup besar, hal itu terlihat dari mayoritas penduduk Aceh Utara yang rataratanya berprofesi sebagai petani,dan khususnya di Desa Blang Pha yang masyarakatnya berprofesi sebagai petani. Kegiatan usaha tani padi bertujuan untuk meningkatkan produktivitas dan peningkatan pendapatan petani agar menghasilkan keuntungan menjadi lebih tinggi.

Desa Blang Pha merupakan salah satu desa di Kecamatan Seunuddon yang mayoritas penduduknya berprofesi sebagai petani padi untuk mencukupi kebutuhan hidup sehari-harinya. Desa Blang Pha mempunyai lahan yang sangat berpotensi untuk melakukan usaha tani padi dikarenakan desa Blang Pha mempunyai tingkat kesuburan tanah yang sangat tinggi dan juga mempunyai luas areal persawahan yang sangat besar yaitu 125,3 hektar. Dengan semakin tinggi tingkat kesuburan tanah, maka tingkat produktivitas padi yang di peroleh petani akan semakin meningkat sehingga tingkat pendapatan petani akan ikut meningkat pula.

Petani di desa Blang Pha terbagi dalam beberapa jenis, seperti di jelaskan dalam table 1 sebagai berikut :

Tabel 1

Jenis-jenis Petani Desa Blang Pha

\begin{tabular}{|l|l|l|}
\hline No & Jenis Petani & Jumlah (Jiwa) \\
\hline 1 & Petani Pemilik lahan & 243 \\
\hline 2 & Petani Penyewa Lahan & 15 \\
\hline 3 & Petani Buruh & 73 \\
\hline Jumlah & $\mathbf{3 3 1}$ Jiwa \\
\hline
\end{tabular}

Sumber: Kantor Keuchik Desa Blang Pha

Pada Tabel 1 di atas, dijelaskan bahwa jenis petani di desa Blang Pha terbagi kedalam tiga jenis, yaitu Petani pemilik lahan,Petani Penyewa lahan dan Petani Buruh. Untuk Petani pemilik Lahan jumlahnya sebesar 243 orang, petani penyewa lahan jumlahnya adalah 15 orang, dan Petani buruh jumlahnya adalah 73 orang.
Berdasarkan hasil survei awal peneliti, pendapatan petani di desa Blang Pha, sebagaimana ditunjukkan dalam tabel 2 sebagai berikut.

Tabel 2

Jumlah Pendapatan Petani Desa Blang Pha

\begin{tabular}{|c|l|l|l|l|l|}
\hline $\begin{array}{c}\mathrm{N} \\
\mathrm{o}\end{array}$ & \multicolumn{1}{|c|}{$\begin{array}{c}\text { Nama } \\
\text { petani }\end{array}$} & $\begin{array}{c}\text { Luas } \\
\text { Lahan }\end{array}$ & $\begin{array}{c}\text { Biaya } \\
\text { Produksi }\end{array}$ & $\begin{array}{c}\text { Hasil } \\
\text { Produksi }\end{array}$ & $\begin{array}{l}\text { Pendapatan } \\
\text { Petani }\end{array}$ \\
\hline 1 & Asnari & $4.100 \mathrm{M}^{2}$ & $\begin{array}{l}\mathrm{Rp} 3.950 .00 \\
0\end{array}$ & $\mathrm{Rp} 10.000 .000$ & $\begin{array}{l}\mathrm{Rp} \\
6.050 .000\end{array}$ \\
\hline 2 & Abdullah & $570 \mathrm{M}^{2}$ & $\mathrm{Rp} \mathrm{500.000}$ & $\mathrm{Rp} 1.450 .000$ & $\mathrm{Rp} \mathrm{950.000}$ \\
\hline 3 & Sofyan & $10.200 \mathrm{M}^{2}$ & $\begin{array}{l}\mathrm{Rp} \\
7.000 .000\end{array}$ & $\begin{array}{l}\mathrm{Rp} \\
37.625 .000\end{array}$ & $\begin{array}{l}\mathrm{Rp} \\
30.625 .000\end{array}$ \\
\hline 4 & Maimun & $3.000 \mathrm{M}^{2}$ & $\begin{array}{l}\mathrm{Rp} \\
2.500 .000\end{array}$ & $\mathrm{Rp} \mathrm{7.525.000}$ & $\begin{array}{l}\mathrm{Rp} \\
5.025 .000\end{array}$ \\
\hline 5 & Salmahdi & $6.000 \mathrm{M}^{2}$ & $\begin{array}{l}\mathrm{Rp} \\
5.700 .000\end{array}$ & $\begin{array}{l}\mathrm{Rp} \\
10.750 .000\end{array}$ & $\begin{array}{l}\mathrm{Rp} \\
5.050 .000\end{array}$ \\
\hline
\end{tabular}

Sumber : Data primer (diolah)

Dari table 2 di atas terlihat bahwa pendapatan petani desa Blang Pha berbeda-beda tergantung dari luas lahan yang di kelola oleh petani. Yaitu asnari mengelola lahan dengan luas lahan $4.100 \mathrm{M}^{2}$ dengan biaya Produksi yang di keluarkan sebesar $\mathrm{Rp} 3.950 .000$ dan Hasil produksi yang diperoleh $\mathrm{Rp} 10.000 .000$ dengan pendapatan yang di peroleh Rp 6.050.000, Abdullah mengelola lahan seluas $570 \mathrm{M}^{2}$ dengan biaya produksi yang di keluarkan sebesar Rp 500.000 dengan hasil produksi Padi sebanyak Rp 1.450.000 dengan jumlah pendapatan yang di peroleh adalah $\mathrm{Rp}$ 950.000, Sofyan mengelola lahan pertanian seluas $10.200 \mathrm{M}^{2}$ dengan biaya produksi yang di keluarkan sebanyak Rp 7.000.000 dengan Hasil produksi yang sebanyak $\mathrm{Rp} \quad 37.625 .000$ dan memperoleh pendapatan sebesar Rp 30.625.000, Maimun mengelola lahan pertanian seluas $3.000 \mathrm{M}^{2}$ dengan biaya produksi yang di keluarkan sebanyak Rp 2.500.000 dengan Hasil produksi padi sebanyak Rp 7.525.000 dengan jumlah pendapatan sebanyak $\mathrm{Rp}$ 5.025.000, Salmahdi mengelola lahan pertanian seluas $6.000 \mathrm{M}^{2}$ dengan biaya produksi yang di keluarkan sebanyak Rp 5.700.000 dengan jumlah produksi padi yang di peroleh sebanyak Rp 10.750.000 dengan jumlah pendapatan yang di peroleh Rp 5.050.000.

Berdasarkan pengamatan Penulis dalam satu tahun petani Desa Blang Pha hanya melakukan proses produksi padi selama dua kali. Pendapatan hanya di peroleh pada waktu panen padi sedangkan pada waktu lain para petani 
menganggur tidak ada pendapatan lain, dan Untuk Biaya Produksi selanjutnya seperti Biaya Pengarapan Lahan, Biaya Bibit, Pupuk dan Pestisida maka petani akan terlibat utang piutang dengan para tengkulak dan akan dibayar pada saat para petani melakukan panen dengan harga yang lebih tinggi sehingga akan menambah biaya produksi. Permasalahan lain yang di hadapi petani adalah penetuan produktivitas di sektor pertanian yaitu seperti masalah pengairan yang menghambat produktifitas petani, penyusutan luas lahan yang di akibatkan oleh industrialisasi dan urbanisasi, terbatasnya kemampuan penguasaan teknologi dan rendahnya kualiatas sumber daya manusia.

Tujuan Penelitian yaitu untuk mengetahui seberapa besarkah pengaruh biaya produksi, luas lahan dan hasil produksi terhadap peningkatan pendapatan petani padi desa Blang Pha Kecamatan Seunuddon.

Bagian kedua dari penetian ini akan membahas tinjauan teoritis, metode penelitiannya disajikan dibagian ketiga, selanjutnya hasil penelitian serta pembahasan dipaparkan bagian keempat dalam penelitian ini, yang selanjutnya pada bagian akhir merupakan kesimpulan dan saran.

\section{TINJAUAN TEORITIS Biaya Produksi}

Biaya adalah kas atau nilai setara kas yang dikorbankan untuk barang dan jasa yang diharapkan dapat memberikan manfaat pada saat ini atau dimasa yang akan datang bagi suatu organisasi(Simamora, 2002).

\section{Macam-macam Biaya Produksi}

Biaya adalah suatu kegiatan yang dilakukan dalamsetiap usaha yang memerlukan pengorbanan fisik danpengorbanan non fisik, baik itu secara langsung maupun tidak langsung.Dalam kegiatan ekonomi setiap kegiatan untuk memperoleh suatu barang dan jasa hal yang sangat diperlukan adalah pengorbanan dari suatu barang dan jasa lainnya, dengan demikian pengorbanan ini dapat diartikan sebagai modal atau biaya.

Biaya dapat di bedakan dalam beberapa macam, yaitu biaya tetap, biaya variabel, dan biaya semi variabel.

\section{Faktor-faktor Produksi}

Faktor produksi adalah segala sesuatu yang dibutuhkan untuk memproduksi barang dan jasa.Faktor produksi terdiri atas alam, tenaga kerja, modal dan keahlian atau sumber daya pengusaha (enterpreneurship).Faktor produksi alam dan tenaga kerja disebut faktor produksi asli (utama) sedangkan modal dan tenaga kerja disebut faktor produksi turunan.

\section{Luas Lahan}

Menurut (Musa, 2008)Luas lahan adalah luas areal persawahan yang akan di tanami padi pada musim tertentu. Pada umumnya luas lahan sawah merupakan lahan pertanian yang berpetakpetak dan di batasi oleh pematangsaluaran untuk menahan/menyalurkan air,yang biasanya ditanami padi tanpa memandang darimana diperolehnya tanah atau status tanah tersebut. Tanah memiliki sifat yang tidak sama dengan faktor produksi lainnya yaitu luas yang relatif tetap dan permintaan akan lahan yang semakin meningkat sehingga sifatnya menjadi langka.

Sawah dibagi menjadi beberapa jenis berdasarkan sistem pengairan/irigasinya yaitu, sawah pengairan teknis, sawah pengairan setengah teknis, sawah pengairan pedesaan, sawah tadah hujan, sawah rawa, sawah rawa pasang surut dan sawah lebak.

\section{Hasil Produksi}

Menurut (Sugiarto, 2002),segala sesuatu yang di hasilkan oleh petani padi. Hasil produksi merupakan suatu kegiatan yang akanmengubah input menjadi output. Kegiatan tersebut dalam ekonomi biasanya di nyatakan dalam fungsi produk, fungsi produk biasanya dinyatakan dalam fungsi produk, fungsi produk dinyatakan dalam jumlah maksimum output yang dapat di hasilkan dari pemakaian jumlah input dengan menggunakan teknologi tertentu.

\section{Pendapatan}

Menurut (Sukirno, 2006) Pendapatan merupakan jumlah penghasilan yang didapatkan oleh penduduk atas hasil prestasi kerjanya dalam satu periode tertentu,baik harian, mingguan, bulanan dan tahunan. Pendapatan adalah arus 
masuk bruto yang ditimbulkan oleh aktivitas sebuah perusahaan dalam periode tertentu, bila arus masuk diakibatkan oleh kenaikan ekuitas dan tidak berasal dari penanaman modal(Ikatan Akuntansi Indonesia, 2009).

\section{Kerangka Konseptual}

Penelitian mencoba mendeskripsikan seberapa besarpengaruh Variabel indenpenden terhadap variabel dependen dengan menggunakan uji simultan. Adapun kerangka berfikir yang digunakan untuk memperjelas pengaruh Biaya Produksi, luas lahan dan hasil produksi terhadap peningkatan pendapatan petani, adalah sebagai berikut:

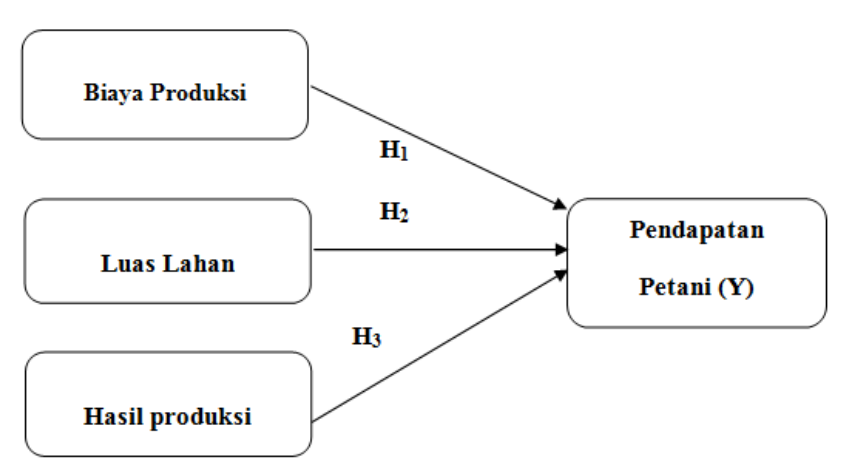

Gambar 1

Kerangka Konseptual

Berdasarkan gambar 1 di atas, kerangka konseptual dalam penelitian ini dapat dijelaskan bahwa variabel dependen yaitu pendapatan petani ( Y) yang dalam hal ini adalah pendapatan petani, di pengaruhi oleh variabel independen yaitu Biaya produksi (X1), Luas lahan (X2) dan Hasil produksi (X3).

\section{Hipotesis}

Agar penelitian ini lebih terarah, maka penulis membuat suatu dugaan sementara tentang hasil penelitian ini yang dirangkum dalam sebuah hipotesis. Dari latar belakang penelitian dan tinjauan teoritis yang telah dikemukakan maka yang menjadi hipotesis dalam penelitian ini adalah:

$\mathrm{H}_{1}$ : Diduga Biaya Produksi berpengaruh terhadap pendapatan Petani.
$\mathrm{H}_{2}$ : Diduga Luas lahan berpengaruh terhadap pendapatan Petani.

$\mathrm{H}_{3}$ : Diduga Hasil Produksi berpengaruh terhadap pendapatan Petani.

\section{METODE PENELITIAN}

\section{Populasi dan Sampel}

Populasi dalam penelitian ini adalah seluruh petani pemilik lahan desa Blang Pha yang berjumlah 243 jiwa. Untuk Menetukan Sampel dalam penelitian ini dilakukan dengan menggunakan rumus Slovin yaitu :

$$
\begin{gathered}
\mathrm{n}=\frac{\mathrm{N}}{1+\mathrm{Ne}^{2}} \\
\mathrm{n}=\frac{243}{1+243(0.1)}=\frac{243}{1+2,43}=\frac{243}{3,43}=70
\end{gathered}
$$

Berdasarkan teknik pengambilan sampel dengan bantuan rumus di atas, maka jumlah sampel dalam penelitian ini adalah sebanyak 70 orang dari total Petani pemilik lahan 243 orang, yang diperoleh sesuai dengan rumus yang digunakan.

\section{Definisi Operasional Variabel}

Definisi operasional variabel merupakan petunjuk bagaimana variabel-variabel dalam penelitian diukur. Untuk memperjelas dan mempermudah pemahaman terhadap variabelvariabel yang akan dianalisis dalam penelitian ini, maka butuh dirumuskan operasional variabel yaitu sebagai berikut:

1. Variabel pendapatan (Y) merupakan pendapatan petani yang diperoleh dari setiap hasil panen yang kemudiannya diubah dalam bentuk \% dan kemudiannya diubah dalam satuan rupiah.

2. Variabel biaya produksi $\left(\mathrm{X}_{1}\right)$ merupakan biaya yang digunakan dalam proses produksi yang kemudiannya diubah dalam bentuk \% yang kemudiannya diubah dalam satuan rupiah.

3. Variabel luas lahan $\left(\mathrm{X}_{2}\right)$ merupakan luas lahan petani yang diubah dalam bentuk \% dan kemudiannya diubah dalam $\mathrm{H}_{\mathrm{a}}$. 
4. Variabel jumlah produksi $\left(\mathrm{X}_{3}\right)$ yaitu hasil produksi petani yang diukur dalam satuan yang kemudiannya diubah dalam bentuk \% dan kemudiannya diubah menjadi $\mathrm{Kg}$.

\section{Metode Analisis Data}

Model ekonometrik yang digunakan dalam penelitian ini adalah regresi linier berganda, sehingga diformulasikan sebagai berikut :

$$
\begin{array}{ll}
\mathbf{Y}=\boldsymbol{\beta}_{\mathbf{0}}+\boldsymbol{\beta}_{\mathbf{1}} \mathbf{X}_{\mathbf{1}}+\boldsymbol{\beta}_{\mathbf{2}} \mathbf{X}_{\mathbf{2}}+\boldsymbol{\beta}_{\mathbf{3}} \mathbf{X}_{\mathbf{3}}+\mathbf{e i} \\
\text { Keterangan : } \\
\mathrm{Y} \quad \text { = Pendapatan } \\
\beta_{0} \quad \text { = Konstanta } \\
\beta_{1,}, \beta_{2}, \beta_{3} & =\text { Koefisienregresivariabel } \\
\mathrm{X}_{1} & =\text { Biaya produksi } \\
\mathrm{X}_{2} & =\text { Luas lahan } \\
\mathrm{X}_{3} & =\text { Hasil produksi } \\
\text { ei } & =\text { Error term (VariabelPenganggu) }
\end{array}
$$

Dikarenakan Variabel dalam penelitian ini berbeda satuannya, untuk menyamakan satuan variabel dalam penelitian ini maka penulis melakukan Log.

$$
\log Y=\beta 0+\beta_{1} \log X 1+\beta_{2} \log X_{2}+\beta_{3} \log X_{3}+\text { ei }
$$

\section{Uji Normalitas}

Uji normalitas, uji ini dipakai untuk mengetahui apakah residual terdistribusi secara normal. Jika adaseperti itu, maka residual akan terdistribusi secara normal dan independen, yaitu tidak samadengan nilai prediksi pada skor yang sebenarnya atau error akan berdistribusi secara simetri padadaerah nilai means sama dengan nol(Ghozali, 2012).

\section{Uji Asumsi Klasik}

Uji asumsi klasi bertujuan untuk mengetahui kondisi data yang dipergunakan dalam penelitian ini. Hal tersebuat di lakukan supaya penelitian ini memperoleh model analisis regresi yang tepat. Dalam penelitian ini terdapat dua pengujian, yaitu : Uji heteroskedastisitas dan UjiMultikolinearitas.

\section{Uji Heterokedastisitas}

Uji Heteroskedastisitas, menurut (Ghozali, 2005) tujuan dari uji ini untuk mengetahui apakah didalam model regresi ada terjadi ketidaksamaan, variance, dari recidual sebuah pengamatan kepada pengamatan lainnya tetap maka disebut Homokedastisitas, apabila berbeda dinamakan Heteroskedastisitas.

\section{Uji Multikolinearitas}

Uji multikolinearitas bertujuan untuk menguji apakah dalam model regresi linier berganda ditemukan adanya korelasiantar variabel bebas (independen). Model regresi linier berganda yang baik seharusnya tidak terjadi korelasi diantara variabel independen. Jika diantara variabel independen saling berkorelasi, maka variabel-variabel ini tidak ortogonal. Variabel ortogonal adalah variabel independen yang nilai korelasi antara sesamanya yaitu sama dengan nol (Ghozali, 2012).

\section{Pengujian Hipotesis \\ Uji Parsial (Uji t)}

Pengujian Parsial (Uji t), pada dasarnya dilakukan bertujuan untuk melihat sejauh mana pengaruhnya suatu variableindependen atau penjelassecara satu-persatu dalam menjelaskan model variabel terikat(Ghozali, 2012).

\section{Uji Simultan ( Uji F)}

Pengujian Simultan (Uji F), pada dasarnya bertujuan untuk mengetahui apa seluruh variabel bebas atau independen yang terdapat dalam model memiliki pengaruhnya dengan bersamaan kepada variabel dependen atau terikat (Ghozali, 2005).

\section{Koefisien Korelasi (r)}

Koefisien korelasi (r) adalah akar dari koefisien determinasi $\left(\mathrm{R}^{2}\right)$. Besarnya hubungan antara variabel satu dengan variabel lain dinyatakan dengan koefisien korelasi yang disimbulkan dengan huruf " $r$ ". Dalam statistik korelasi dapat diberikan pengertian sebagai hubungan antara dua variabel atau lebih(Sugiyono, 2007).

\section{Koefisien Determinasi $\left(\mathrm{R}^{2}\right)$}

Koefisien determinasi (Adjusted $\mathrm{R}^{2}$ ) pada dasarnya mengukur sejauh mana tenagavariasipada penerangan model variabel dependen.Nilai koefisien determinasi yaitudiantara 
nol dan satu.Nilai Adjusted $\mathrm{R}^{\mathbf{2}}$ yang kecil artinya kemampuan variabel-variabel independen didalam penjelasan model variabel terikat sangat dibatasi. Nilai yang berdekatan satu artinya variabelvariabel bebas menimbulkan hampir seluruhpenjelasan yang diperlukandalam menebak model variabel terikat (Ghozali, 2012).

\section{HASIL PENELITIAN DAN PEMBAHASAN}

\section{Gambaran Umum}

Kecamatan Seunuddon merupakan sebuah kecamatan yang ada di kabupaten Aceh Utara, ibu kota kecamatan Seunuddon adalah Keudee Seunuddon, luas kecamatan Seunuddon adalah $100,63 \mathrm{~km}^{2}$ atau 3,05\% dari keseluruhan wilayah di kabupaten Aceh Utara $\left(3.296,86 \mathrm{Km}^{2}\right.$ ) yang terbagi dalam 3 kemukiman dengan jumlah desa yaitu 33 desa.

Adapun nama-nama desa yang terdapat di kecamatan Seunuddon adalah Blang Tue, Meurubo Puntong, Manee Kawan, Tanjong Pineung, Alue Kiran, Alue Barueh, Keudee Simpang Jalan, Cot Kafiraton, Paya Dua Ujong, Tanjong Dama, Paya Dua Uram, Lhok Geulituet, Matang Anoe, Lhok Rambideng, Blang Pha, Matang Jelikat, Darul Aman, Cot Trueng, Menasah Sagoe, Matang Puntong, Matang Panyang, Cot Patisah, Alue Capli, Simpang Peut, Ulee Titi, Lhok Puuek, Ulee Rubeek Barat, Matang Lada, Matang Karieng, Ulee Matang, Ulee Rubeek Timu, Bantayan, Dan Teupin Kuyuen.

Batasan kecamatan seunuddon antara lain :

1. Sebelah utara berbatasan dengan Selat Malaka.

2. Sebelah selatan berbatasan dengan Kecamatan Baktiya.

3. Sebelah barat berbatasan dengan Kecamatan Baktiya.

4. Sebelah timur berbatasan dengan Kecamatan Jambo Aye.

Namun yang menjadi yang menjadi lokasi dalam penelitian ini adalah desa Blang Pha. Desa Blang Pha mempunyai luas sekitar 333 ha dimana penggunaan lahan sawah dan bukan lahan sawah, luas arel lahan sawah sekitar 125,3 ha dan bukan lahan sawah 207,7 ha. Desa Blang pha termasuk dalam kemukiman Pantee Seunuddon dengan jarak desa dari ibu kota kecamatan Seunuddon sekitar 3,0 Km dan jarak desa Blang Pha dengan ibu kota kabupaten Aceh Utara adalah $30 \mathrm{~km}$.

Adapun jumlah masyarakat desa Blang Pha tahun 2014 sejumlah 564 jiwa, pada tahun 2015 sejumlah 575 jiwa, pada tahun 2016 bertambah menjadi 593 jiwa, pada tahun 2017 bertambah menjadi 691 jiwa. Pada umumnya masyarakat desa Blang Pha bekerja sebagai petani padi untuk memenuhi kebutuhan hidup sehari-hari. Masyarakat desa Blang Pha memiliki luas lahan untuk menanam padi sebesar 125,3 ha dengan jumlah hasil produksi sebanyak 523 ton. Dengan fasilitas dan sarana pertanian di desa Blang Pha pada tahun 2017 memiliki traktor / hand traktor sebanyak 8 buah sedangkan mesin perontok gabah 8 buah.

\section{Hasil Analisis Data \\ Hasil Analisis Regresi Linier Berganda Tabel 3 \\ Regresi Linier Berganda}

\begin{tabular}{|c|c|c|c|c|}
\hline \multicolumn{5}{|c|}{$\begin{array}{l}\text { Dependent Variable: LOG(Y) } \\
\text { Method: Least Squares } \\
\text { Date: } 08 / 07 / 18 \text { Time: } 11: 58 \\
\text { Sample: } 170 \\
\text { Included observations: } 70\end{array}$} \\
\hline Variable & Coefficient & Std. Error & t-Statistic & Prob. \\
\hline C & 10.93573 & 0.674044 & 16.22406 & 0.0000 \\
\hline $\mathrm{LOG}(\mathrm{X} 1)$ & -0.513092 & 0.076255 & -6.728622 & 0.0000 \\
\hline $\mathrm{LOG}(\mathrm{X} 2)$ & 1.518165 & 0.116084 & 13.07815 & 0.0000 \\
\hline LOG(X3) & 0.017852 & 0.037515 & 0.475876 & 0.6357 \\
\hline R-squared & 0.831979 & \multicolumn{2}{|c|}{ Mean dependent var } & 15.95520 \\
\hline Adjusted R-squared & 0.824341 & \multicolumn{2}{|c|}{ S.D. dependent var } & 0.202317 \\
\hline S.E. of regression & 0.084795 & \multicolumn{2}{|c|}{ Akaike info criterion } & -2.041727 \\
\hline Sum squared resid & 0.474547 & \multicolumn{2}{|c|}{ Schwarz criterion } & -1.913241 \\
\hline Log likelihood & 75.46043 & \multicolumn{2}{|c|}{ Hannan-Quinn criter. } & -1.990691 \\
\hline F-statistic & 108.9357 & \multicolumn{2}{|c|}{ Durbin-Watson stat } & 1.781879 \\
\hline Prob(F-statistic) & 0.000000 & & & \\
\hline
\end{tabular}

Dependent Variable: LOG(Y)

Method: Least Squares

Date: 08/07/18 Time: 11:58

Sample: 170

Included observations: 70

Sumber: Hasil Penelitian (data diolah 2018)

Berdasarkan pada tabel diatas maka persamannya adalah sebagai berikut:

$\log \mathrm{Y}=10.93573-0.0513092 \log \mathrm{X} 1+$ $1.518165 \log X 2+0.017852 \log X 3$ 
Dari persamaan model diatas dapat diketahui bahwa variabel konstanta mempunyai nilai10.93573, artinya apabila variabel Biaya produksi $\left(\mathrm{X}_{1}\right)$, Luas lahan $\left(\mathrm{X}_{2}\right)$ dan Hasil produski $\left(\mathrm{X}_{3}\right)$, dianggap konstan (tidak berubah) maka nilai Pendapatan (Y) juga akan konstan sebesar $10.93573 \%$. Koefesien dari Biaya produksi $\left(\mathrm{X}_{1}\right)$ mempunyai nilai sebesar - 0.0513092, artinya apabila variabel Biaya produksi meningkat $1 \%$ maka pendapatan petani akan menurun sebesar $0.051309 \%$. Koefesien dari Luas lahan $\left(\mathrm{X}_{2}\right)$ mempunyai nilai sebesar 1.518165, apabila variabel luas lahan meningkat $1 \%$ maka nilai variabel pendapatan petani akan meningkat sebesar $1.518156 \%$. Koefesien dari Hasil produksi mempunyai nilai sebesar 0.017852 , artinya apabila variabel hasil produksi $\left(\mathrm{X}_{3}\right)$ meningkat $1 \%$ maka nilai variabel pendapatan petaniakan meningkat sebesar $0.017852 \%$.

\section{Hasil Uji Asumsi Klasik}

\section{Hasil Uji Heterokedastisitas}

\section{Tabel 4}

\section{Uji Heterokedastisitas}

Heteroskedasticity Test: White

\begin{tabular}{lclc}
\hline \hline $\begin{array}{l}\text { F-statistic } \\
\text { Obs*R- }\end{array}$ & 1.174388 & Prob. F(3,66) & 0.3262 \\
$\begin{array}{l}\text { squared } \\
\text { Scaled } \\
\text { explained }\end{array}$ & 3.547327 & Prob. Chi-Square(3) & 0.3147 \\
SS & 10.66791 & Prob. Chi-Square(3) & 0.0137 \\
\hline \hline
\end{tabular}

Sumber : Hasil Penelitian (data olah, 2018)

Berdasarkan pada Tabel diatas dapat dilihat bahwa tidak terjadi heteroskedastisitas dalam penelitian ini. Hal ini karena nilai probabilitas obs*R-Square sebesar 0.3147 maka lebih besar dari 0,05 .

\section{Hasil Uji Multikolinearitas}

\section{Tabel 5}

\section{Uji Multikolinearitas}

Variance Inflation Factors

Date: 08/14/18 Time: 19:21

Sample: 170

Included observations: 70

\begin{tabular}{cccc}
\hline \hline Variable & $\begin{array}{c}\text { Coefficient } \\
\text { Variance }\end{array}$ & $\begin{array}{c}\text { Uncentered } \\
\text { VIF }\end{array}$ & $\begin{array}{c}\text { Centered } \\
\text { VIF }\end{array}$ \\
\hline \hline C & 0.454335 & 4423.223 & NA \\
LOG $(X 1)$ & 0.005815 & 13072.30 & 4.467544 \\
LOG(X2) & 0.013476 & 8931.114 & 4.918622
\end{tabular}

\begin{tabular}{llll}
$\operatorname{LOG}(\mathrm{X} 3)$ & 0.001407 & 3674.674 & 1.349470 \\
\hline
\end{tabular}

Sumber: Hasil Penelitian (data diolah, 2018)

Berdasarkan Tabel 5 di atas, nilai centeredVIF dibawah 10 dan menunjukkan tidak terjadinya multikolinearitas antar variabel bebas dalam model regresi. Hasil olah data diketahui bahwa nilai centeredVIF variabel Biaya produksi(X1) sebesar 4.467544, variabel luas lahan(X2) sebesar 4.918622 dan hasil produksi(X3) sebesar 1.349470.

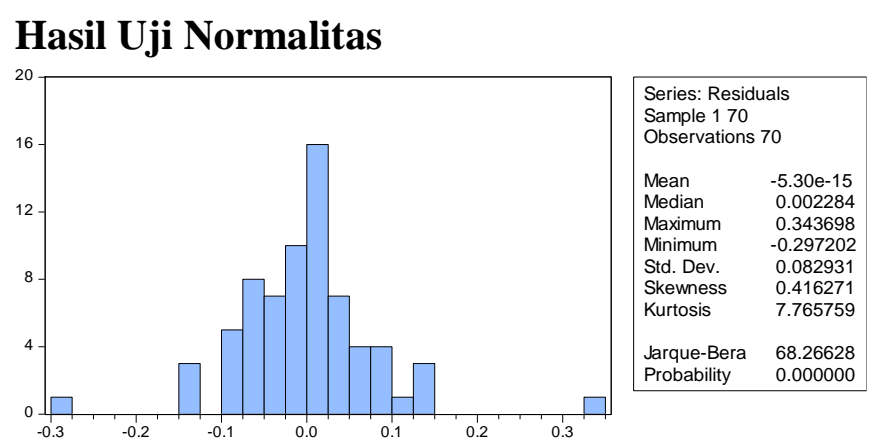

Sumber: Hasil penelitian (Data Diolah: 2018)

\section{Gambar 2}

\section{Uji Normalitas}

Dari gambar 2 diatas dapat dilihat bahwa dalam penelitian ini tidak terjadi normalitas. Hal ini di karenakan nilai J-B hitung sebesar 68.26628 lebih kecil dari nilai $\mathrm{C}^{2}$ tabel sebesar 85.96491 atau $68.26628<85.96491$ maka nilai residual terdistribusi normal.

\section{Pengujian Hipotesis \\ Pengujian Parsial (Uji t)}

Berdasarkan hasil regresi pada tabel di atas maka dapat dilihat bahwa variabel biaya produksi

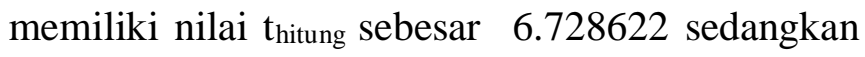
nilai $t_{\text {tabel }}$ sebesar 1.99656.Dari nilai tersebut menunjukkan bahwa nilai $t_{\text {hitung }}>\mathrm{t}_{\text {tabel }}$ maka dapat disimpulkan bahwa $\mathrm{H}_{1}$ diterima dan ditolak $\mathrm{H}_{0}$ yang artinya variabel Biaya produksi $\left(\mathrm{X}_{1}\right)$ secara parsial berpengaruh signifikan terhadap variabel pendapatan petani.

Selanjutnya dari tabel diatas dapat juga dilihat bahwa variabel luas lahan memiliki nilai $t_{\text {hitung }}$ sebesar 13.07815 dan t-tabel sebesar 1.99656. maka hal ini juga menunjukan bahwa nilai $t_{\text {hitung }}>\mathrm{t}_{\text {tabel, }}$, maka dapat disimpulkan bahwa $\mathrm{H}_{0}$ ditolak dan terima $\mathrm{H}_{1}$ yang artinya variabel luas 
lahan $\left(\mathrm{X}_{2}\right)$ secara parsial berpengaruh signifikan terhadap variabel pendapatan petani.

Kemudian dari tabel diatas dapat juga dilihat bahwa variabel Hasil produksi memiliki nilai $t_{\text {hitung }}$ sebesar 0,475876 dan t-tabel sebesar 1.99656. maka hal ini juga menunjukan bahwa nilai $t_{\text {hitung }}<\mathrm{t}_{\text {tabel}}$, maka dapat disimpulkan bahwa $\mathrm{H}_{0}$ diterima dan ditolak $\mathrm{H}_{1}$ yang artinya variabel Hasil produksi $\left(\mathrm{X}_{3}\right)$ secara parsial tidak berpengaruh signifikan terhadap variabel pendapatan petani.

\section{Pengujian Simultan (Uji f)}

Berdasarkan hasil regresi pada tabel diatas dapat dilihat bahwa nilai $F_{\text {hitung }}$ sebesar 108.9357sedangkan nilai $F_{\text {tabel }}$ sebesar 2,74 Maka hal ini menjukan bahwa nilai $F_{\text {hitung }}>$ nilai $F_{\text {tabel, }}$ jadi dapat disimpulkan bahwa dengan tingkat keyakinan 95\% variabel bebas secara simultan berpengaruh signifikan terhadap Pendapatan Petani.

\section{Koefisien Korelasi (r)}

Berdasarkan pada tabel hasil regresi diatas dapat dilihat bahwa nilai korelasi (r) sebesar 0.907932266 maka artinya terdapat hubungan yang sangat kuat antara variabel bebas dengan variabel terikat karena secara individu variabel biaya produksi, luas lahan dan hasil produksi mempengaruhi variabel pendapatan petani.

\section{Koefisien Determinasi $\left(\mathbf{R}^{\mathbf{2}}\right)$}

Dari tabel hasil regresi diatas dapat dilihat nilai koefesien determinasi $\left(\mathrm{R}^{2}\right)$ yaitu sebesar 0,824341 artinya perubahan-perubahan dalam variabel pendapatan petani, keterkaitannya dapat dijelaskan oleh variabel Biaya produksi, Luas lahan dan hasil produksi sebesar $82.4341 \%$ sedangkan sisanya sebesar $17.5659 \%$ dijelaskan oleh variabel lain yang tidak di masukan dalam penelitian ini.

\section{KESIMPULAN DAN SARAN Kesimpulan}

Berdasarkan hasil penelitian ini, maka terdapat beberapa kesimpulan yaitu sebagai berikut:
1. Variabel Biaya produksi berpengaruh negatif dan signifikan terhadap pendapatan petani padi di Desa Blang Pha Kecamatan Seunuddon Kabupaten Aceh Utara.

2. Variabel Luas lahan berpengaruh negatif dan signifikan terhadap pendapatan petanidi Desa Blang Pha Kecamatan Seunuddon Kabupaten Aceh Utara.

3. Variabel Hasil produksi positif dan tidak signifikan terhadap variabel Pendapatan petanidi Desa Blang Pha Kecamatan Seunuddon Kabupaten Aceh Utara.

\section{Saran}

Berdasarkan hasil penelitian ini, maka terdapat beberapa saran yaitu sebagai berikut:

1. Bagi peneliti selanjutnya, peneliti sarankan agar menambah variabel lain yang tidak diteliti dalam penelitian ini agar dapat mengetahui apa-apa saja variabel lain yang dapat mempengaruhi tingkat pendapatan petani.

2. Bagi petani, peneliti sarankan agar dapat menggali lagi pengetahuan mengenai profesinya agar memperoleh hasil yang maksimal.

3. Bagi pemerintah, peneliti sarankan agar mempermudah para petani dengan cara membangun infrastruktur seperti jalan, jembatan, membuat pelatihan dan lain-lain sebagainya yang dapat mendukung para petani khususnya petani padi.

\section{DAFTAR PUSTAKA}

Astuti, Y. (2013). Efektivitas Pelaksanaan Program Sistem Pertanian Terintegrasi (Simantri) Terhadap Peningkatan Pendapatan Petani. Denpasar: Universitas Mahasaraswati. Ghozali, I. (2005). Model Persamaan Struktural. Konsep, Dan Aplikasi Dengan Program Amos 16.1. Semarang: UNDIP.

Ghozali, I. (2012). Aplikasi Analisis Multivariate dengan Program IBM SPSS20. Semarang: Universitas Diponegoro.

Ikatan Akuntansi Indonesia. (2009). Standar Akuntansi Keuangan, PSAK No: 1.Penyajian Laporan Keuangan. Jakarta: Salemba Empat. 
Lindawati. (2015). Pengaruh Hasil Produksi

Tanaman Padi Terhadap Kesejahteraan

Petani Di Kecamatan Nisam. Lhokseumawe:

Universitas Malikussaleh.

Mangkuprawira, T. . dan A. . H. (2007).

Manajemen Mutu Sumber Daya Manusia.

Bogor: Ghalia indonesia.

Musa, S. (2008). Lahan Perkebunan Atau Area Sawah. jakarta: CV. Insan Jaya.

Nilawati. (2015). Analisis Faktor-faktor yang Mempengaruhi Pendapatan Petani Padi di Desa Alue Lim. Lhokseumawe: Universitas Malikussaleh.

Simamora, H. (2002). Akuntansi Manajemen. Jakarta: Salemba Empat.

Sugiarto, E. (2002). Psikologi Pelayanan dalam Industri Jasa. Jakarta: Gramedia Pustaka Utama.

Sugiyono. (2007). Metode Penelitian Bisnis (Pendekatan Kuantitatif, Kualitatif, dan $R \& D)$. Bandung: Alfabeta. 